\title{
An exploratory study of environmental practices in two Brazilian higher education institutions
}

\author{
Karina Rabelo Ogasawara Vieira ${ }^{a}$, Rosane Aparecida Gomes Battistelle ${ }^{a}$, \\ Barbara Stolte Bezerra ${ }^{\mathrm{a},}{ }^{*}$, Rosani de Castro ${ }^{\mathrm{a}}$, Charbel Jose Chiappetta Jabbour ${ }^{\mathrm{b}}$, \\ Rafael Mattos Deus ${ }^{\text {a }}$ \\ a Engineering School of Bauru (FEB) of UNESP, Univ Estadual Paulista, Bauru Campus, Av. Eng. Luiz Edmundo Carrijo Coube, $n^{\circ}$ 14-01, Vargem Limpa, CEP, \\ 17033-360, Bauru, São Paulo, Brazil \\ ${ }^{\mathrm{b}}$ Montpellier Research in Management, 2300; Avenue des Moulins, 34185, Montpellier, Cedex 4, France
}

\section{A R T I C L E I N F O}

\section{Article history:}

Received 30 October 2017

Received in revised form

16 February 2018

Accepted 25 March 2018

Available online 27 March 2018

\section{Keywords:}

Higher education

Sustainability

Environment

Environmental management systems

University

\begin{abstract}
A B S T R A C T
This study aimed to identify the barriers and motivations that influence the adoption of sustainable practices in higher education institutions (HEIs). A multiple case study approach was used to analyze the influence of the barriers and motivations identified in the literature on two Brazilian HEIs. Five propositions were identified and discussed: Government Directives coercively boost the adoption of EMS practices in HEIs; stakeholders boost the adoption of EMS practices in HEIs; the combination of topdown and participatory approaches is essential for maintaining EMS practices in HEIs; the adoption of EMS practices in HEIs tends to face the challenges of several barriers; the adoption of EMS practices in HEIs tends to be motivated by a variety of factors. This study has certain limitations common to qualitative research: case studies do not provide generalizations, and research results are valid only within limited contexts. It was suggested further in-depth research into the role of bureaucracy in pursuing sustainability in HEIs. Additionally, "bureaucracy" should also be considered a significant barrier.
\end{abstract}

() 2018 Elsevier Ltd. All rights reserved.

\section{Introduction}

The literature presents several reports of the successful implementation of environmental management systems (EMS) in HEIs (Price, 2005; Jones et al., 2012; León-Fernández and DomínguezVilches, 2015). However, full and accurate figures remain unknown, since there is no national or global registry (Disterheft et al., 2012). Additionally, the adoption of EMS is, in general, voluntary in HEIs around the world, although in Sweden all higher education institutions must implement an EMS (Sammalisto and Brorson, 2008).

Lozano et al. (2015) conducted international research to explore the commitment and implementation of sustainable development in higher education. According to these authors, studies of this nature are located, for the most part, in Europe (80\%), followed by North America, Australia and Oceania, Latin America and the

\footnotetext{
* Corresponding author.

E-mail addresses: rabelo.karina@gmail.com (K.R.O. Vieira), rosane@feb.unesp.br (R.A.G. Battistelle), barbarabezerra@feb.unesp.br (B.S. Bezerra), rosani@feb.unesp.br (R. Castro), cjcjabbour@gmail.com (C.J.C. Jabbour), rafaelmdeus@gmail.com (R.M. Deus).
}

Caribbean and, finally, Africa. Their results corroborate the assertion of Barth and Rieckmann (2013) that sustainability studies in developing countries are still scarce. It is noteworthy that even among European countries there are relatively high levels of disproportionality in the field of sustainable development (SzopikDepczyńska et al., 2017).

Brazil, the country chosen for this study, is part of the BRICS group and is among the ten largest economies in the world (World Economic Forum, 2017). In 2016, it had 8,052,254 students enrolled in 34,366 different undergraduate courses, offered by 2407 HEIs (Brazil, 2017).

Due to the specific structures and characteristics of HEIs, it may be questioned whether a campus-based EMS can work successfully, since it is inevitable that barriers will arise in the process of change. Therefore, it is crucial to identify and characterize these barriers, in order to reduce or overcome them (Lozano, 2006a). However, it is not easy to predict the repercussions of a barrier or combination of barriers for a sustainability initiative. A barrier can impact the progress of EMS implementation, which is highly dependent on the circumstances and context of the individual institution (Velazquez et al., 2005).

For this reason, it is essential to identify the main motivations 
and barriers to the adoption of EMS practices and how these will affect the success of EMS implementation in a HEI (Sammalisto and Brorson, 2008; Disterheft et al., 2012). Therefore, this study aims to analyze these motivations and barriers, through an exploratory study in two important Brazilian HEIs.

One of the main outcomes of this research is the literature review on sustainability in HEIs. Furthermore, five research propositions shown to be substantiated in the literature are presented, providing new insights that may be relevant for understanding sustainability in HEIs in emerging economies. The emergence of a new barrier to sustainability in HEIs is also presented: 'bureaucracy'.

The following sections will present the theoretical background to barriers and motivations regarding the implementation of EMS in HEI, the methodological approach used, the results obtained and discussion, and the conclusions of the paper.

\section{Theoretical background}

During the Decade of Education for Sustainable Development (2004-2015), some authors proposed sustainability initiatives for greening HEIs. The most frequently cited (according to Web of Science and Scopus) are the Framework for Achieving Campus Sustainability (Alshuwaikhat and Abubakar, 2008), Model for a Sustainable University (Velazquez et al., 2006), and Graphical Assessment of Sustainability in Universities (GASU) (Lozano, 2006b).

Universities have adopted EMS in order to work towards becoming more sustainable, reducing negative environmental impacts and building greener campuses (Alshuwaikhat and Abubakar, 2008). The EMS helps organizations to achieve their environmental goals, reducing the damage that their activities cause to the environment, through a set of practices and environmental management procedures (Inoue et al., 2013).

Clarke and Kouri (2009) discuss several EMS approaches for HEIs, ranging from formal certified models to informal uncertified ones. Examples include: ISO 14001; the Osnabrück model; Higher Education 21 (HE21); Environmental Management System SelfAssessment Checklist; Auditing Instrument for Sustainability in Higher Education (AISHE); and the Campus Sustainability Model.

Nonetheless, the process of implementing an EMS faces both motivators and barriers. Barnes and Jerman (2001) point out some barriers encountered by three universities from South Carolina in implementing an EMS in their institutions. The authors identify two main barriers: the lack of awareness of the environmental impact of HEIs due to the intangibility of the "educational service" developed, and the complex hierarchy of HEI implementation due to various departments' differing levels of autonomy. Moreover, they found that many faculty members and administrators were not interested in environmental issues, and that the turnover of staff and students in HEIs, especially when a key team member leaves for another job, breaks the continuity of the EMS. They also report the following barriers: difficulties in carrying out environmental audits due to a lack of standardization; the inability to keep accurate and reliable records for comparison; and the belief that conducting an audit is a highly complicated task.

Vierbahn (2002) points out the difficulties in motivating and involving university staff. This view is supported by Barnes and Jerman (2001) and Ifegbesan et al. (2017), who found in one Nigerian university that no more than $40.5 \%$ of students expressed serious concern about solid waste practices. Vierbahn (2002) also identifies another barrier in the implementation of the EMS developed by Osnabrück University: the difficulty and timeconsuming nature of data collection. A lack of requirement to maintain and record data leads to its unavailability.
A survey conducted by Savely et al. (2007) identifies some barriers to the implementation of EMS in North American HEIs. One main barrier was a lack of communication between the institution and senior management, as almost half of institutions failed to regularly report environmental performance issues to the top management. Similarly, senior management did not regularly review the environmental programs of their institutions. Another key issue was the lack of commitment of human and financial resources to EMS. While some institutions have at least one full-time employee responsible for environmental management activities, others have to convince existing faculty and staff members to include environmental management in their activities. In addition, a lack of confidence in the benefits of EMS was reported by approximately $20 \%$ of the institutions surveyed.

Sammalisto and Brorson (2008) surveyed barriers to EMS at the University of Gävle, which was given ISO 14001 certification in 2004. A questionnaire distributed to all university departments revealed the following barriers: lack of time - environmental management is often seen as extra work, not included in daily activities; lack of information - in general, people do not know how to incorporate environmental management into their individual activities; personal interest - some people are less sensitive to environmental issues; and the feeling that government directives are generally coercive, if necessary.

On the other hand, Cubbage et al. (2003) show how North Carolina State University, Duke University, and the North Carolina Division of Forest Resources gained both Forest Stewardship Council (FSC) and Sustainable Forestry Initiative (SFI) certification for their forest. The motivators reported were work environment improvement, professional image improvement, higher managerial morale and knowledge extension.

Sammalisto and Arvidsson (2005) report that a government directive made EMS mandatory for all public organizations in Sweden since 1996, as a political and environmental goal. The main barriers they faced were that EMS was not a priority, a lack of monitoring by top management and a lack of financial resources. On the other hand, the central motivators included: external reputation, such as image, goodwill, and credibility; interest of faculty, staff, and students; engagement and support of the top management; and involvement of faculty, staff, and students.

Price (2005) presented the case of the Glamorgan University, located in Wales, which implemented the ISO 14001 in 2002. The consensus was that committing to continuous improvement would improve the environmental sustainability of the organization, regarding its activities and the activities of those who work for the organization. The motivations include interests of faculty, staff, and students and the engagement and support of top management, which increases motivation, as also reported by Sammalisto and Arvidsson (2005).

Disterheft et al. (2012) identified 47 European HEIs across 14 countries which have an EMS. A questionnaire was used to collect data on the profile of these institutions and the types of EMS implemented, as well as to identify the motivations for implementing an EMS. Environmental awareness/social responsibility was considered the most important motivator in EMS implementation, with $80 \%$ of the HEIs evaluated classifying it as important or very important.

Stakeholder motivation leads to a good relationship between faculty, staff, and students. In this way environmental responsibility becomes personal, leading to environmental awareness, which is the most important motivator since people are the driving force for implementing an EMS (Price, 2005). Therefore, stakeholders play an important role toward campus sustainability (Arroyo, 2017). Jabbour et al. (2013) showed that individual motivation and individual environmental management actions are the main drivers for 
institutional change.

Accordingly, Disterheft et al. (2012) suggest a combination of the top-down approach, which is effective in achieving environmental improvements in HEIs, and the participatory approach, which encourages education for sustainability on campus. This combination allows for the reconciliation and redefinition of the interests of students, faculty, and staff, facilitates information disclosure regarding existing environmental practices, contributes to building a more sustainable future, and promotes adaptive management and knowledge acquisition by social partners, government, etc. Without top management support, environmental initiatives and projects may be limited to a department or a campus area, or even be discontinued due to the retirement of a manager or faculty member or a lack of resources, among other causes.

The next section will present the research method employed to analyze the barriers and motivations for successful EMS implementation.

\section{Research method}

The procedures used to identify the barriers and motivations for implementing EMS in HEIs were based on a structured literature review, as proposed by Lage and Godinho Filho (2010) and employed by Jabbour (2010). The main steps in this process are shown in Fig. 1. Table 1 shows the combinations of keywords used and the number of articles returned by searching in Web of Science and Scopus, using the standard search functions of the respective databases. Initially, the keywords "Environmental Management Systems AND University" were used, returning 727 papers in Web of Science and 2331 in Scopus. A second search with the keywords "Environmental Management Systems AND Higher Education" found 240 papers in Web of Science and 678 in Scopus. A further search was performed using "ISO 14001 AND University", which found another 23 papers in Web of Science and 38 in Scopus. A fourth search was made using the keywords "ISO 14001 AND Higher Education" which found 9 papers in Web of Science and 12 in Scopus.

This research used the inclusion criteria of articles published in the last 5 years or those that had received at least one citation; duplicate articles were also excluded. Thus, the preliminary results from the database searches (Table 1) were reduced to 52 articles. After reading the abstracts of these, 18 articles were selected for the final analysis, and these papers were analyzed regarding barriers and motivations (Table 2).

Thereby, after conducting the literature review it was possible to systematize the main barriers and motivations described therein and presented in Table 3. Table 4 presents the five theoretical propositions which were used in the case study (Yin, 2001; Srivetbodee et al., 2017). Yin (2001) reports that propositions extracted from literature reviews can be used as a guide to case study analysis, and can also help to structure the case study and define alternative hypotheses to be examined. However, this may also lead to focusing on certain data and ignoring others.

The case study approach was used to analyze a current issue (Yin, 2001): the motivators and barriers to adopting EMS practices found in the literature, examined in the context of two HEIs located in the state of São Paulo, Brazil.

In the present study, the two HEIs selected are denoted by the names "Alpha HEI" and "Beta HEI". They are public, free higher education institutions with a daily flow of around 6000 visitors each. Both HEIs are part of major universities in the state of São Paulo. Alpha HEI is part of a decentralized university with 24 campuses, while Beta HEI is part of a university that has seven campuses. Table 5 shows the characteristics of the campuses studied in each HEI. Alpha HEI's campus has about 1000 staff

\section{Step 1: Definition of keywords}
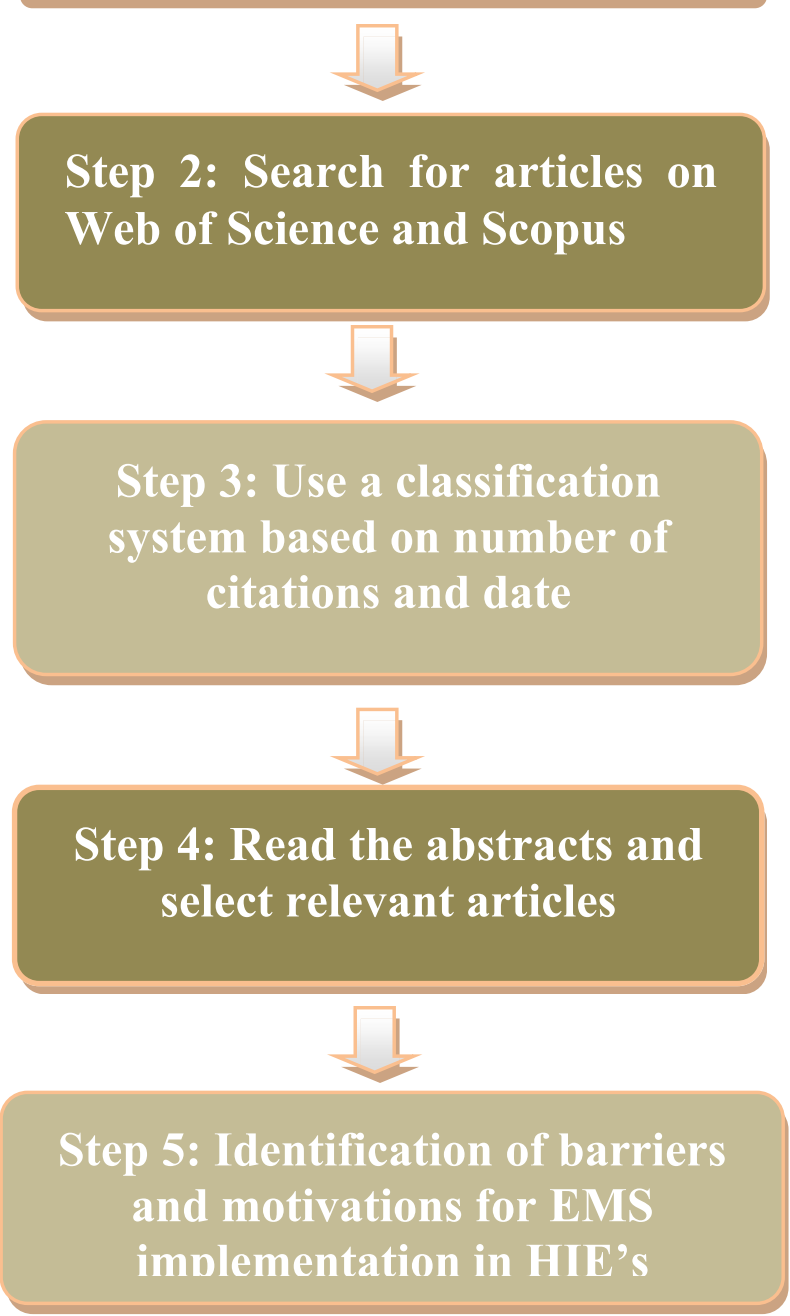

Fig. 1. Structured literature review steps. Adapted from Lage and Godinho Filho (2010).

members and 5000 students; it therefore plays a significant role in the São Paulo higher education system. It is considered a highquality institution and one of the best in the country. Beta HEI's campus also has about 1000 staff members and about 5000 students and patients, and includes an affiliated hospital.

Brazil was chosen for this study because, as a member of BRICS, it is among the major emerging economies in the world (Wilson and Purushothaman, 2003). It has hosted significant environmental milestones such as the United Nations Conference on Sustainable Development, held in Rio de Janeiro in June of 2012 (Leal Filho, 2015). Despite this, very few studies have investigated sustainability in higher education in emerging economies. The research framework used is depicted in Fig. 2, along with the five propositions elaborated in Table 4.

These HEIs were chosen because they have similar characteristics, which can be classified into two groups:

1) General waste - usually more visible, such as disposable cups, food scraps, plastic, paper, aluminum cans, dry leaves, etc.

2) Laboratory waste - chemical and biological waste, such as wood shavings, laboratory animal carcasses or tissue, heavy metals, chemicals, etc. 
Table 1

Database search results. Procedures for conducting the Case Study.

\begin{tabular}{ll}
\hline Keywords & Number of Papers \\
\cline { 2 - 2 } & Web of Science \\
\hline "Environmental Management Systems" AND “University" & 727 \\
"Environmental Management Systems" AND “Higher Education” & 240 \\
"ISO 14001 AND University" & 23 \\
"ISO 14001 AND Higher Education" & 9 \\
\hline
\end{tabular}

Table 2

Classification of papers analyzed regarding barriers and motivations.

\begin{tabular}{|c|c|c|c|}
\hline Papers & EMS & Barriers & Motivations \\
\hline $\begin{array}{l}\text { Barnes and Jerman (2001) } \\
\text { Vierbahn (2002) } \\
\text { Shriberg (2002) } \\
\text { Cubbage et al. (2003) } \\
\text { Price (2005) } \\
\text { Sammalisto and Arvidsson (2005) } \\
\text { Ferreira et al. (2006) } \\
\text { Tauchen and Brandli (2006) } \\
\text { Savely et al. (2007) } \\
\text { Savely et al. (2007) } \\
\text { Sammalisto and Brorson (2008) } \\
\text { Alshuwaikhat and Abubakar (2008) } \\
\text { Clarke and Kouri (2009) } \\
\text { Jain and Pant (2010) } \\
\text { Bero et al. (2012) } \\
\text { Disterheft et al. (2012) } \\
\text { Jones et al. (2012) } \\
\text { Boman and Andersson (2013) }\end{array}$ & $\begin{array}{l}\mathbf{a} \\
\mathbf{\square} \\
\mathbf{\square} \\
\mathbf{\square} \\
\mathbf{\square} \\
\mathbf{\square} \\
\mathbf{\square} \\
\mathbf{\square} \\
\mathbf{\square} \\
\mathbf{\square} \\
\mathbf{\square} \\
\mathbf{\square} \\
\mathbf{\square} \\
\mathbf{\square} \\
\mathbf{\square}\end{array}$ & $\mathbf{\square}$ & $\begin{array}{l}\square \\
\square\end{array}$ \\
\hline
\end{tabular}

The present study assumes that the HEIs studied employ some environmental management practices, and that certain motivators and barriers influence the implementation of these practices. Based on the theoretical concepts discussed, three research assumptions are proposed. The data were collected through interviews, observations, and document analysis.

The case study protocol and set of interview questions which guided the interviews are presented in Table 6. The interviews lasted approximately $1 \mathrm{~h}$ each and were recorded and transcribed for analysis. The respondents interviewed in the HEIs were academic directors, administrative directors and those responsible for environmental management. In Alpha HEI the campus director was indicated as the representative of environmental management affairs, while Beta HEI indicated an environmental engineer as responsible for its environmental management. Thus, three interviews were conducted in each institution.

The observed findings were summarized, analyzed and grouped
Table 4

Research propositions.

\begin{tabular}{l}
\hline Research Proposition \\
\hline Proposition 1: Government Directives coercively boost the adoption of EMS \\
practices in HEIs. \\
Proposition 2: Stakeholders boost the adoption of EMS practices in HEIs. \\
Proposition 3: The combination of top-down and participatory approaches \\
through stakeholders' engagement is essential for adopting EMS practices in \\
HEIs. \\
Proposition 4: The adoption of EMS practices in HEIs tends to face the challenges \\
of multiple barriers. \\
Proposition 5: The adoption of EMS practices in HEIs tends to be motivated by a \\
variety of factors.
\end{tabular}

according to the case study questions in order to strengthen the considerations presented in the results and discussion sections. Similarly, the documents obtained were analyzed, and the results identified were grouped according to the case study questions presented in the case study protocol.

The sources of evidence used allowed for data triangulation, contributing to ensuring the quality of the data collection and analysis (Yin, 2013).

The data obtained were subsequently organized, and individual analyses and discussions of the data are presented in the following section.

\section{Results and discussion}

In this section the results found for research propositions 1 to 5 will be presented for each of the two HEIs studied. Section 4.1 will present the discussion of these results.

Proposition 1. Government Directives coercively boost the adoption of EMS practices in HEIs.

Brazilian universities are not legally required to adopt EMS practices. The National Policy on Solid Waste instituted by Law No. 12,305, August of 2010 (Brazil, 2010), encourages the development

Table 3

Selected barriers and motivations related to EMS implementation in HEIs.

\begin{tabular}{|c|c|}
\hline Selected Barriers & Selected Motivations \\
\hline $\begin{array}{l}\text { Lack of clarity as to the environmental damage caused by the HEI } \\
\text { HEI hierarchy differing from that of a company } \\
\text { Lack of interest or motivation from faculty members and technical-administrative staff } \\
\text { Turnover of staff and students in the HEI } \\
\text { Difficulty of carrying out environmental audits } \\
\text { Challenging and time-consuming data collection } \\
\text { Lack of financial resources } \\
\text { EMS not being a priority } \\
\text { Lack of support and monitoring from top management } \\
\text { Lack of communication between the institution and top management } \\
\text { Understaffing } \\
\text { Lack of confidence in the potential benefits of EMS. } \\
\text { Lack of time. } \\
\text { Lack of knowledge and information on EMS. }\end{array}$ & $\begin{array}{l}\text { Improvement of work environment and spirit of cooperation } \\
\text { Improvement of professional image } \\
\text { Higher managerial morale } \\
\text { Knowledge extension } \\
\text { Interest of faculty, staff, and students } \\
\text { Engagement and support of top management } \\
\text { Involvement of faculty, staff, and students } \\
\text { Government directives } \\
\text { External reputation factors such as image, goodwill, and credibility } \\
\text { Personal interest } \\
\text { Environmental awareness/social responsibility }\end{array}$ \\
\hline
\end{tabular}


Table 5

Characteristics of Alpha and Beta HEIs' campuses.

\begin{tabular}{lll}
\hline Characteristic & Alpha HEI & Beta HEI \\
\hline Built area of campus & $52,403.15 \mathrm{~m}^{2}$ & $156,850 \mathrm{~m}^{2}$ \\
Campus organization & 3 colleges and & 1 college, 1 administrative unit, \\
& 1 administrative unit & 1 hospital \\
Employee composition & 1000 employees & 1000 employees \\
Daily flow & 5000 students & 5000 people, including students and patients \\
Unit of analysis in the case study & EMS practices, Alpha HEI & EMS practices, Beta HEI \\
\hline
\end{tabular}

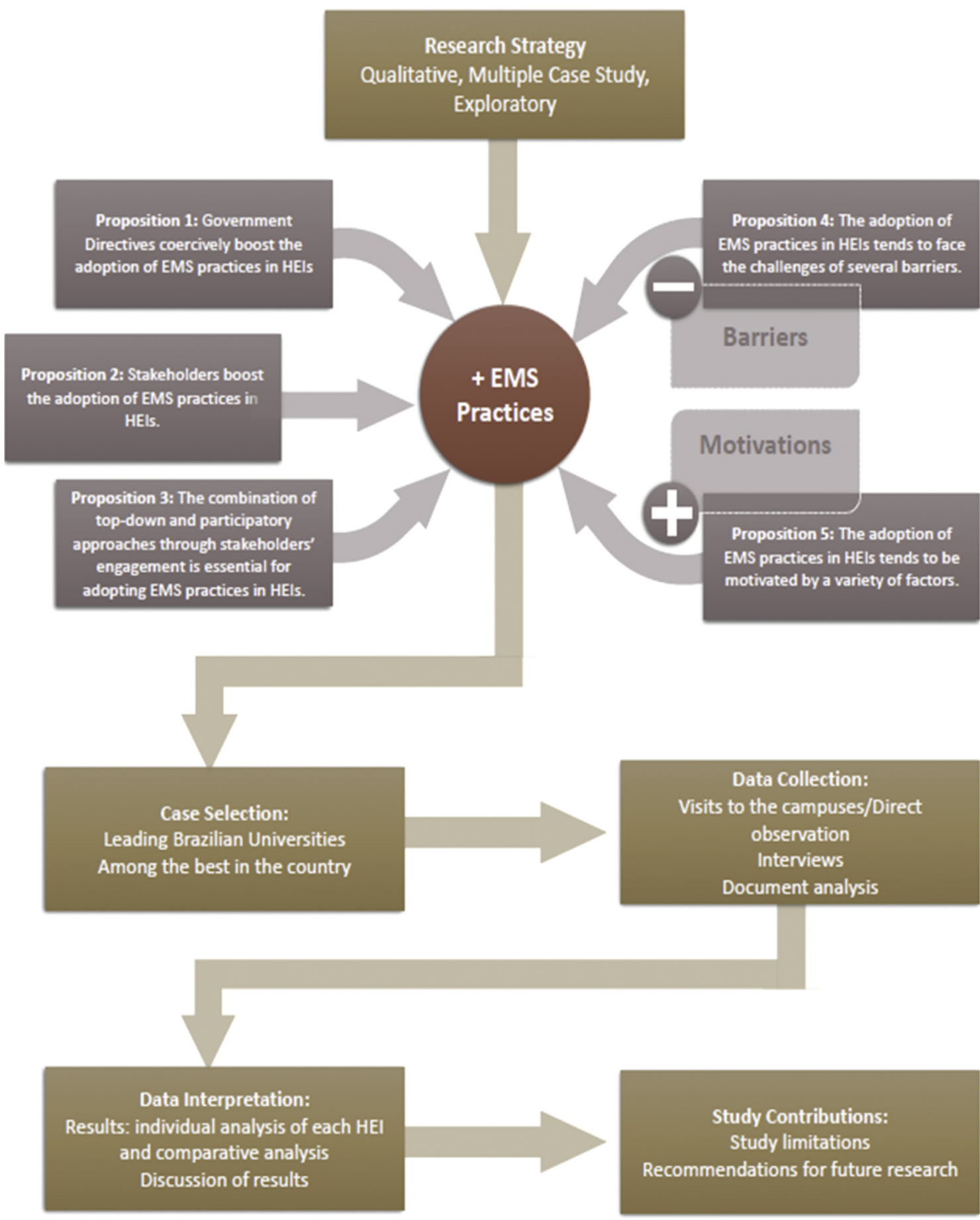

Fig. 2. Research framework. 
Table 6

Case study protocol.

\begin{tabular}{|c|c|}
\hline Objective & $\begin{array}{l}\text { To identify how motivators and barriers influence the adoption } \\
\text { of Environmental Management System practices in higher } \\
\text { education institutions, and to test the five research propositions } \\
\text { defined during the literature review. }\end{array}$ \\
\hline Questions & $\begin{array}{l}\text { - How are environmental issues handled in the HEI? } \\
\text { - What EMS practices are adopted by the HEI? } \\
\text { - What are the barriers to the adoption of EMS practices? } \\
\text { - What are the motivators to the adoption of EMS practices? } \\
\text { - Does the government boost the adoption of EMS practices? } \\
\text { - Do the stakeholders influence the adoption of EMS practices? } \\
\text { - How are the environmental management programs/projects } \\
\text { institutionalized? } \\
\text { - How have the environmental management programs/projects } \\
\text { influenced the work routine? } \\
\text { - How should an EMS be implemented? Through the initiative } \\
\text { of top management or all stakeholders? }\end{array}$ \\
\hline $\begin{array}{l}\text { Field of } \\
\text { analysis }\end{array}$ & Motivators and barriers to the adoption of EMS practices in HEIs \\
\hline Place & São Paulo State, Brazil \\
\hline Time period & Between August 2013 and August 2014 \\
\hline $\begin{array}{l}\text { Source of } \\
\text { evidence }\end{array}$ & Direct observations, documents, and interviews \\
\hline
\end{tabular}

of EMS in organizations but does not oblige it.

Alpha HEI complies with the government-supervised disposal of laboratory waste, and accordingly has instituted the following programs:

- Acquisition and Disposal Program - promotes conscious acquisition aimed at reducing consumption of chemicals and identifying and recording products to be discarded, due to the hazards associated with this type of product and the regulations determined by federal policy, ANVISA (The National Health Surveillance Agency), and the Fire Department.

- Reuse and Decontamination Program: Alpha HEI is responsible for the decontamination and reuse of the materials used in all its campuses. However, not all chemicals can be reused, and their disposal can be expensive.

- Alpha HEI's laboratories comply with the ISO/IEC 17025 requirements - General Requirements for the Competence of Testing and Calibration Laboratories - including the traceability of materials, although they do not have accreditation. Laboratory waste is sent to off-site storage facilities. There are five facilities; each one receives a specific type of material, and they are all adequately built to handle this type of material without contaminating soil, water, causing explosions, etc.

\section{According to Alpha HEI's administrative director:}

"Many actions are carried out; we have chemistry and physics laboratories, and their waste must be disposed of properly. A company collects wood shavings, mice carcasses or tissue etc., i.e., everything that requires proper disposal. The campus has replaced all traditional incandescent light bulbs with fluorescent light bulbs, following the government's recommendations."

Beta HEI complies with the adequate disposal of laboratory waste, and has developed a campus waste plan according to Law 12,305/2010. According to Beta HEI's environmental engineer:

"There is a recycling program that has been institutionalized, implemented, and funded by the university. In 1994, for the first time, the university discussed environmental issues with the community. Talking to the entire university community made a big difference in education, both socially and culturally (because we have the basic employee and the professor, who has a postgraduate degree); waste became a common subject for everybody. Due to waste generation, a discussion about consumption was held in educational meetings. Accordingly, there were some pedagogic actions related to the 3Rs: Reduce consumption, Reuse, and separating for Recycling."

The recycling program in Beta HEI is comprehensive and includes the following environmental practices:

Proposition 2. Stakeholders boost the adoption of EMS practices in HEIs.

- Waste recycling - recyclable waste is disposed of in blue bags and regular waste in black bags. Cleaning services are outsourced, and employees are trained to send waste to the storage facility, where it is stored in specific areas according to its type: regular waste, recyclable waste, and organic waste. The waste is then sent from this facility either to a recycling cooperative or to landfill.

- Organic waste treatment - food waste generated by the university restaurant, fallen leaves and tree trimmings are composted. Part of the composted material is used in the campus yard and gardens, and part is donated to the community.

- Chemical and biological waste treatment - chemical waste is treated, recovered, and made available to the source that generated it. Biological waste resulting from health care services undergoes treatment such as autoclaving or incineration and, besides this special treatment, has to be packaged and transported according to regulations and properly disposed of.

- Reducing the use of paper and plastic - all employees are encouraged to use double-sided printing, including for printing theses and dissertations. According to the academic director, each department is entitled to use only one ream of paper per month.

Both HEIs have adopted EMS practices. It is noticeable that in Alpha HEI environmental initiatives began in several departments, particularly in the biology department.

Alpha HEI does not have a proper and formal environmental policy. The respondents agreed that there are specific actions for the proper treatment of laboratory waste, environmental reserves, and consumption reduction, but that some environmental issues are handled according to necessity. According to the academic director:

"There is not an environmental management policy; we resolve each issue as needed."

The administrative director stated that:

"We have not defined an environmental management policy. Some projects have been created, mainly by Biology Department professors ... The facility constructions always follow the rules and guidelines determined by the Secretariat of Environment and CETESB (Environmental Company of Sao Paulo State)."

The campus director stated that:

"The institution undertakes initiatives through courses and projects, which have not yet been institutionalized by the Office of the Provost in an EMS."

Individual departments have the autonomy to carry out environmental actions, but since these actions are not integrated in a 
common database, many end up being discontinued over time. For example, it was reported that the biology department requested the purchase of specialized containers to encourage selective waste disposal in common areas of the campus. However, people routinely mix paper, plastics, glass, metals, and organic waste in all trash containers. Thus, most of the waste is mixed and therefore destined for landfill. According to the academic director of Alpha HEI:

"The main waste generated is paper, perhaps followed by printer cartridges. All paper is collected and placed in a box. A man collects this material and donates it for sale, preventing it from being wasted ... This action is a concern of our department; I do not know if the same occurs in the classrooms ... We always try to create awareness among our employees: Aren't you going to use the computer? Turn it off! When you leave a room, turn off the light; this is my constant concern. Sometimes, Human Resources offer courses to remind us of these actions and other important information."

The reports showed that the effectiveness of EMS practices is linked to their institutionalization. Beta HEI stakeholders, despite initial resistance, eventually learned new habits because of institutionalized environmental programs. According to the academic director of Beta HEI:

"We believed that one ream of paper per month would not be enough, but imposing a limit was good because you learn; I print on both sides of the sheet, except when I have to file an official document. Within our offices, sometimes, I don't have much paper left, so I get some from those who have the largest amount left."

It was found that each employee used ten disposable cups per day for drinking water and coffee. Disposable cups were replaced with individual reusable cups or mugs, which were produced by the institution itself. These cups were for use by the entire university community, including in its restaurants. The campus engineer of Beta HEI stated:

"This mug process was not a simple process; it took a while for people to adjust to it because you are removing something they feel comfortable with, but it was successfully institutionalized."

With regards to the recycling program, the academic director of Beta HEI stated that:

"They develop awareness among the sectors and students. As for the disposable cups, a more durable mug has been distributed so that we do not have to use disposable cups, including the students; during the first academic week, a lecture is given to present the recycling program guidelines."

In Beta HEI the Rational Use of Water Program aims to prevent waste of natural resources through equipment optimization, change of habits, and waste minimization. It was observed that the faucets and toilet flushing systems were water-efficient and that pigeon droppings on sidewalks were washed away using highpressure surface cleaners. The Efficient Use of Energy Program implements energy-saving actions and educates the university community about the importance of energy efficiency and the importance of sustainable use of natural resources.

Proposition 3. The combination of top-down and participatory approaches through stakeholders' engagement is essential for adopting EMS practices in HEIs.
In Alpha HEI, some environmental actions have been reported, but as they are not institutionalized, they may end up being discontinued:

"Paper is one of the main wastes generated by the administrative departments. We have not been using recycled paper because of the policy of purchasing at the lowest price, i.e., the bidding process. We have had printer problems associated with the use of recyclable paper. We have been trying to promote the use of individual reusable mugs. This project is still under discussion and was developed by a biology department professor."

- Energy conservation program - according to the respondents, the institution has developed a manual containing instructions and information about the use of resources and equipment, energy saving, and basic guidelines on how to proceed. The campus has followed CPFL (Sao Paulo Energy Company) recommendations, replacing all traditional incandescent bulbs with fluorescent light bulbs.

- Policy to reduce the use of paper and plastic - according to the administrative director:

- There was an attempt to replace white paper with recycled paper around the year 2000, but due to the bidding process through the Electronic Purchase System (BEC), in which the lowest price wins the bid, and the poor quality of the recycled paper, the traditional white paper has not been replaced. The campus director highlighted that these initiatives need to be undertaken again, and that he supports the "no photocopy" policy because of easy access to digital technology.

- Water conservation program - the laboratories previously used $80-100 \mathrm{~L}$ of water to make $1 \mathrm{~L}$ of distilled water, but since adopting the use of reverse osmosis, they have being using a lot less water. This initiative was first adopted in the Alpha HEI laboratories, and was subsequently adopted in the other campuses of the university by the Office of the Provost.

- Environmental training - The campus director said that they offer environmental awareness lectures and courses, but that these are not very frequent and are not designed or designated for the entire campus community.

It may be noted that Alpha HEI's environmental initiatives are now only top-down, and sometimes separate from departments. This means that such initiatives are dependent on the work of an individual teacher or research group. When there is a change in senior management, there is no continuous training or use of a participatory approach.

According to the academic director of Alpha HEI, the energy conservation program distributed stickers to remind users to turn off equipment at the end of their activity. However, these decals got old or were removed, meaning that efficient use of energy now depends on each individual's conscience.

Beta HEI is part of a university that has had an established Environmental Management Committee since 2012, a committee which seeks to promote environmental sustainability across the institution's campuses. Its fundamental principles were established in a letter and an environmental proposal in 2009, which led to the passing of an Ordinance for forming Working Groups (WG) to define an approach to implementation of Environmental Management in all university campuses:

- Waste Management Working Group - aims to lay down the guidelines for hazardous solid and liquid waste management within the university. However, units are responsible for applying these guidelines according to their own specificities. 
- Education Working Group - promotes training to encourage sustainable actions, offering subsidies to increase awareness of socio-environmental issues and individual and collective responsibility. It stimulates the "learning by participating" process. All personnel participating in the training courses have the responsibility to train a group of 30 people and, together with them, develop and implement environmental projects.

Beta HEI has an environmental management website detailing its environmental programs. Some units of the university have environmental educators, who provide a link between the Office of the Provost and the other campuses of the institution. The environmental educator is exclusively dedicated to environmental management.

\subsection{Comparative analysis of the study cases}

Since Beta HEI has sought to institutionalize an environmental management program and has made an effort to educate the community about environmental issues, it can be said that all respondents viewed the barriers (Table 7) and motivations (Table 8) from the perspective of a top-down approach. In Alpha HEI, on the other hand, only the campus director has a top-down view, as this respondent considers the implementation of EMS as the responsibility of the Office of the Provost. The directors consider the participatory approach to be ideal.

Proposition 4. The adoption of EMS practices in HEIs tends to face the challenges of multiple barriers.

Respondents from both institutions identified the barrier 'the EMS is not seen as a priority for the university community (students, staff, and faculty)' (Table 7). The Beta HEI environmental engineer, responsible for its environmental management, emphasized the difficulties in increasing motivation and raising interest in environmental issues when identifying barriers.

The Alpha HEI campus director did not identify some of these barriers because this respondent believes that future EMS adoption must be carried out by the Office of the Provost. This perception results from the decentralized structure of the institution, with the respondent identifying the bureaucratic characteristic of Alpha HEI as a barrier, and adding that: "We have sought to develop environmental initiatives and programs, but we do not have an institutionalized environmental policy; there are difficulties, such as philosophical, natural, cultural, and financial difficulties." According to the Alpha HEI academic director:

"The academic director has a four-year mandate. When a director is replaced, some projects may be discontinued because they are not formalized by the Office of the Provost. An Environmental Management System would be very effective, but everyone has to cooperate. Are we concerned about the environment? Yes, we are, but it is not seen as a priority, and we should be an example."

The Alpha HEI administrative director identified all of the barriers listed in Table 5. The Beta HEI administrative director considered 'EMS not seen as a priority' to be the primary barrier, believing that this is the reason why it has not yet been implemented.

Accordingly, it is clear that the fact that Beta HEI handles environmental management institutionally is the reason why the barriers 'lack of financial resources', 'lack of support and monitoring by the top management', and 'lack of communication between the institution and top management' were not identified in its case. In contrast, the decentralized structure of Alpha HEI is one of the reasons why these same barriers were identified.

Proposition 5. The adoption of EMS practices in HEIs tends to be motivated by a variety of factors.

As for the motivations (Table 6), the Alpha HEI campus director did not identify three of these motivators because this interviewee believes that protecting the institution's reputation and image and keeping up professional morale is the job of the manager.

The Alpha HEI academic director did not identify the engagement and support of top management as a motivation because some projects had been discontinued over time as they were not institutionalized by the Office of the Provost. The administrative director identified all of the motivations listed in Table 6 .

The Beta HEI environmental engineer did not identify two of the motivations, arguing that students, faculty, and staff are hardly interested in collaborating and that there is little involvement of faculty and staff. According to the respondents, external reputation, a spirit of cooperation, and high managerial morale are very important.

Since Beta HEI is part of a prestigious national university, the respondents believe they have to protect this image. The academic director and the administrative director identified all of the

Table 7

Barriers identified by Alpha and Beta HEIs' respondents.

\begin{tabular}{|c|c|c|c|c|c|c|}
\hline \multirow[t]{2}{*}{ Barriers } & \multicolumn{3}{|c|}{ Alpha HEI respondents' considerations } & \multicolumn{3}{|c|}{ Beta HEI respondents' considerations } \\
\hline & $\begin{array}{l}\text { Campus } \\
\text { Director }\end{array}$ & $\begin{array}{l}\text { Academic } \\
\text { director }\end{array}$ & $\begin{array}{l}\text { Administrative } \\
\text { director }\end{array}$ & $\begin{array}{l}\text { Environmental } \\
\text { engineer }\end{array}$ & $\begin{array}{l}\text { Academic } \\
\text { director }\end{array}$ & $\begin{array}{l}\text { Administrative } \\
\text { director }\end{array}$ \\
\hline \multicolumn{7}{|l|}{ EMS is not a priority } \\
\hline \multicolumn{7}{|l|}{ Lack of clarity as to the environmental damage caused by the HEI } \\
\hline \multicolumn{7}{|l|}{ HEI hierarchy is different from that of a company } \\
\hline \multicolumn{7}{|l|}{$\begin{array}{l}\text { Lack of interest or motivation by faculty members and technical- } \\
\text { administrative staff }\end{array}$} \\
\hline \multicolumn{7}{|l|}{ Turnover of staff and students in the HEI } \\
\hline \multicolumn{7}{|l|}{ Difficulty of carrying out environmental audits } \\
\hline \multicolumn{7}{|l|}{ Challenging and time-consuming data collection } \\
\hline \multicolumn{7}{|l|}{ Lack of financial resources } \\
\hline \multicolumn{7}{|l|}{ Understaffing } \\
\hline \multicolumn{7}{|l|}{ Lack of confidence in the potential benefits of EMS } \\
\hline \multicolumn{7}{|l|}{ Lack of support and monitoring from top management } \\
\hline \multicolumn{7}{|l|}{$\begin{array}{l}\text { Lack of communication between the institution and top } \\
\text { management }\end{array}$} \\
\hline \multicolumn{7}{|l|}{ Lack of time } \\
\hline \multicolumn{7}{|l|}{ Lack of EMS } \\
\hline knowledge and information & & & & & & \\
\hline
\end{tabular}


Table 8

Motivations identified by Alpha and Beta HEIs' respondents.

\begin{tabular}{|c|c|c|c|c|c|c|}
\hline \multirow[t]{2}{*}{ Motivations } & \multicolumn{3}{|c|}{ Alpha HEI respondents' considerations } & \multicolumn{3}{|c|}{ Beta HEI respondents' considerations } \\
\hline & $\begin{array}{l}\text { Campus } \\
\text { Director }\end{array}$ & $\begin{array}{l}\text { Academic } \\
\text { director }\end{array}$ & $\begin{array}{l}\text { Administrative } \\
\text { director }\end{array}$ & $\begin{array}{l}\text { Environmental } \\
\text { engineer }\end{array}$ & $\begin{array}{l}\text { Academic } \\
\text { director }\end{array}$ & $\begin{array}{l}\text { Administrative } \\
\text { director }\end{array}$ \\
\hline Interest of faculty, staff, and students & $\mathbf{\square}$ & $\mathbf{\square}$ & $\mathbf{\square}$ & & $\mathbf{a}$ & $\mathbf{\square}$ \\
\hline Engagement and support of the top management & $\mathbf{\square}$ & & $\mathbf{\square}$ & $\mathbf{\square}$ & $\mathbf{\square}$ & $\mathbf{\square}$ \\
\hline Involvement of faculty, staff, and students & $\square$ & $\mathbf{\square}$ & $\mathbf{\square}$ & & $\mathbf{\square}$ & $\mathbf{\square}$ \\
\hline Government directives & $\mathbf{\square}$ & $\mathbf{\square}$ & $\mathbf{\square}$ & $\mathbf{\square}$ & $\mathbf{\square}$ & $\mathbf{\square}$ \\
\hline $\begin{array}{l}\text { External reputation, such as image, good will, and } \\
\text { credibility }\end{array}$ & & $\mathbf{\square}$ & $\mathbf{\square}$ & $\mathbf{\square}$ & $\mathbf{\square}$ & $\mathbf{\square}$ \\
\hline $\begin{array}{l}\text { Improvement of work environment and spirit of } \\
\text { cooperation }\end{array}$ & $\mathbf{\square}$ & $\mathbf{\square}$ & $\mathbf{\square}$ & $\mathbf{a}$ & $\mathbf{\square}$ & $\mathbf{\square}$ \\
\hline Professional image improvement & & $\mathbf{\square}$ & $\mathbf{\square}$ & $\mathbf{\square}$ & $\mathbf{\square}$ & $\mathbf{\square}$ \\
\hline Higher managerial morale & & $\mathbf{\square}$ & $\mathbf{\square}$ & $\mathbf{\square}$ & $\mathbf{\square}$ & $\mathbf{\square}$ \\
\hline Knowledge extension & $\square$ & $\mathbf{\square}$ & $\mathbf{\square}$ & $\mathbf{\square}$ & $\mathbf{\square}$ & $\square$ \\
\hline Personal interest & $\overline{\mathbf{a}}$ & $\overline{\mathbf{a}}$ & $\bar{\square}$ & $\overline{\mathbf{a}}$ & $\overline{\mathbf{a}}$ & $\overline{\mathbf{a}}$ \\
\hline Environmental awareness/social responsibility & $\overline{\mathbf{\square}}$ & $\overline{\mathbf{a}}$ & $\overline{\mathbf{a}}$ & $\overline{\mathbf{a}}$ & $\overline{\mathbf{a}}$ & $\overline{\mathbf{\square}}$ \\
\hline
\end{tabular}

motivations listed in Table 8.

\subsection{Discussions}

The success of EMS adoption showed a relationship between the barriers and motivations encountered in each HEI. Comparing the proportions of Barriers and Motivations (Tables 4 and 5) identified by each HEI, Alpha HEI highlighted fewer motivations (88\%) and more barriers (74\%), indicating the less successful adoption of EMS practices. On the other hand, Beta HEI identified more motivations (94\%) and fewer barriers (40\%), indicating more successful adoption of EMS practices. Fig. 3 presents a framework for interpreting the cases analyzed.

Proposition 1 was confirmed due to the government regulations concerning the handling of controlled and hazardous materials, which affected both HEIs' laboratories. However, Brazil has not exerted legal pressure upon HEIs to adopt EMS. Proposition 2 was confirmed because the concern of stakeholders (faculty, staff, and students) about environmental issues has been shown to boost the adoption of EMS practices in HEIs. Unfortunately, individual or isolated initiatives undertaken by some departments end up being discontinued, confirming Proposition 3, which reinforces the importance of the combination of top-down and participatory approaches. Propositions 4 and 5 can be considered as validated, although there were slight differences observed between the two cases.

Finally, "bureaucracy" emerged as an additional significant barrier, capable of explaining some of the differences observed between Alpha and Beta HEIs. Bureaucracy has hampered proactive environmental management in Alpha, and has impeded more advanced approaches to managing environmental issues. The adoption of an EMS would integrate environmental practices into a common database, align the interests of the university community, and improve the sustainability of all campuses of both institutions. However, this was not the observed reality.

It was observed that certain barriers were experienced differently by Alpha and Beta HEIs. Beta HEI's respondents did not identify 'lack of support and monitoring from top management', 'lack of communication between the institution and top management' or 'lack of financial resources' as barriers. However, Alpha HEI did. Alpha HEI is part of a university with campuses spread throughout the state of São Paulo, which makes communication with top management difficult and consumes financial resources. Bureaucracy seems to be an additional challenge. The Office of the

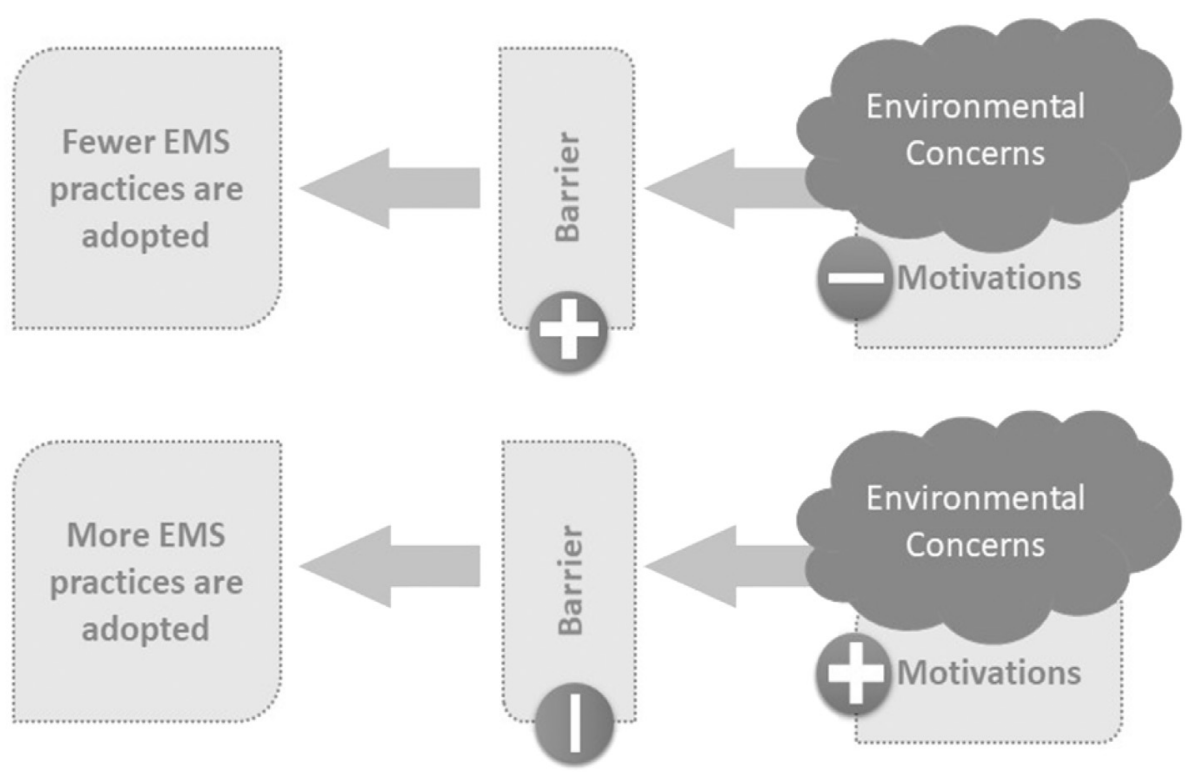

Fig. 3. Relationship between barriers, motivations, and adoption of EMS practices. 
Provost of Alpha HEI has not established any advisory group similar to the Environmental Management Committee of Beta HEI. Therefore, Alpha HEI showed greater difficulty in handling environmental management.

\section{Final considerations}

The present study has contributed to the identification of the motivations and barriers to EMS implementation in HEIs. An exploratory study was carried out to investigate how these motivators and barriers influence the adoption of EMS environmental practices in Brazilian HEIs. This study has additionally identified that bureaucracy is a significant barrier to the implementation of EMS practices in universities. It seems to be responsible for the differences observed regarding the environmental performance of Alpha and Beta institutions.

This study has shown that the presence of more motivations and fewer barriers leads to more successful adoption of EMS practices. Each of the propositions presented was confirmed. Proposition $1-$ 'Government Directives coercively boost the adoption of EMS practices in HEIs' - was shown to be true, even if these practices are applied only in the proper handling of hazardous materials in laboratories. Proposition 2 - 'stakeholders boost the adoption of EMS practices in HEIs' - was proven in the initiatives of departments to develop environmental projects involving students, faculty, and staff. Proposition 3 - 'the combination of top-down and participatory approaches is essential for maintaining EMS practices in HEIs' - is perceived as necessary by both institutions, although they use different environmental management strategies.

This study has certain limitations common to qualitative research: case studies do not provide generalizations, and research results are valid only within limited contexts. Further research is suggested to develop understanding of the role of bureaucracy in HEIs pursuing sustainability.

\section{References}

Alshuwaikhat, H.M., Abubakar, I., 2008. An integrated approach to achieving campus sustainability: assessment of the current campus environmental management practices. J. Clean. Prod. 16 (16), 1777-1785.

Arroyo, P., 2017. A new taxonomy for examining the multi-role of campus sustainability assessments in organizational change. J. Clean. Prod. 140, 1763-1774.

Barnes, P., Jerman, P., 2001. Developing an environmental management system for a multiple-university consortium. J. Clean. Prod. 10 (13), 33-39.

Barth, M., Rieckmann, M., 2013. Current trends and approaches in research in higher education for sustainable development e an international literature review from 1992 e 2012. Paper Presented at the ERSCP-EMSU, Istanbul.

Bero, B.N., Doerry, E., Middleton, R., Meinhardt, C., 2012. Challenges in the development of environmental management systems on the modern university campus. Int. J. Sustain. High. Educ. 13 (2), 133-149.

Brazil, 2010. Ministério do Meio Ambiente. Lei $\mathrm{n}^{\circ}$ 12.305, de 2 de agosto de 2010. Institui a Política Nacional de Resíduos Sólidos; altera a Lei no 9.605, de 12 de fevereiro de 1998; e dá outras providências. Available in. http://www.mma.gov. br/pol\%C3\%ADtica-de-res\%C3\%ADduos-s\%C3\%B3lidos. (Accessed 27 October 2017).

Brazil, 2017. Instituto Nacional de Estudos e Pesquisas Educacionais Anísio Teixeira. Sinopse do Ensino Superior. Available in. http://portal.inep.gov.br/web/guest/ sinopses-estatisticas-da-educacao-superior. (Accessed 27 October 2017).

Boman, J., Andersson, U.P., 2013. Eco-labelling of courses and programs at University of Gothenburg. J. Clean. Prod. 48, 48-53.

Clarke, A., Kouri, R., 2009. Choosing an appropriate university or college environmental management system. J. Clean. Prod. 17 (11), 971-984.

Cubbage, F., Moore, S., Cox, J., Jervis, L., Edeburn, J., Richter, D., Boyette, W. Thompson, M., Chesnutt, M., 2003. Forest certification of state and university lands in North Carolina - a comparison. J. For. 101 (8), 26-31.

Disterheft, A., Caeiro, S.S.F.S., Ramos, M.R., Azeiteiro, U.M.M., 2012. Environmental Management Systems (EMS) implementation processes and practices in
European higher education institutions - top-down versus participatory approaches. J. Clean. Prod. 31, 80-90.

Ferreira, A.J.D., Lopes, M.A.R., Morais, J.P.F., 2006. Environmental management and audit schemes implementation as an educational tool for sustainability. J. Clean. Prod. 14 (9-11), 973-982.

Ifegbesan, A.P., Ifegbesan, A.P., Ogunyemi, B., Ogunyemi, B., Rampedi, I.T., Rampedi, I.T., 2017. Students' attitudes to solid waste management in a Nigerian university: implications for campus-based sustainability education. Int. J. Sustain. High Educ. 18 (7), 1244-1262.

Inoue, E., Arimura, T.H., Nakano, M., 2013. A new insight into environmental innovation: does the maturity of environmental management systems matter? Ecol. Econ. 94, 156-163.

Jabbour, C.J.C., 2010. Greening of business schools: a systemic view. Int. J. Sustain. High Educ. 11 (1), 49-60.

Jabbour, C.J.C., Sarkis, J., Jabbour, A.B.S., Govindan, K., 2013. Understanding the process of greening of Brazilian business schools. J. Clean. Prod. 61 (15), 25-35.

Jain, S., Pant, P., 2010. Environmental management systems for educational institutions: a case study of TERI University, New Delhi. Int. J. Sustain. High. Educ. 11 (3), 236-249.

Jones, N., Panoriou, K. Thiveou, S., Roumeliotis, S., Allan Clark, J.R.A., Evangelinos, K.I., 2012. Investigating benefits from the implementation of environmental management systems in a Greek university. Clean Technol. Environ. Pol. 14 (4), 669-676.

Lage, M., Godinho Filho, M., 2010. Variations of the kanban system: literature review and classification. Int. J. Prod. Econ. 125 (1), 13-21.

Leal Filho, W., 2015. The future we want key issues on sustainable development for sustainable development. Int. J. Sustain. High Educ. 16 (1), 112-129.

León-Fernández, Y., Domínguez-Vilches, E., 2015. Environmental management and sustainability in higher education: the case of Spanish Universities. Int. J. Sustain. High Educ. 16 (4), 440-455.

Lozano, R., 2006a. Incorporation and institutionalization of SD into universities: breaking through barriers to change. J. Clean. Prod. 14, 9-11.

Lozano, R., 2006b. A tool for a graphical assessment of sustainability in universities (GASU). J. Clean. Prod. 14, 963-972.

Lozano, R., Ceulemans, K., Alonso-Almeida, M., Huisingh, D., Lozano, F.J., Waas, T., Lambrechts, W., Lukman, R., Hugé, J., 2015. A review of commitment and implementation of sustainable development in higher education: results from a worldwide survey. J. Clean. Prod. 108, 1-18.

Price, T.J., 2005. Preaching what we practice: experiences from implementing ISO 14001 at the university of glamorgan. Int. J. Sustain. High Educ. 6 (2), 161-178.

Sammalisto, K., Arvidsson, K., 2005. Environmental management in Swedish higher education: directives, driving forces, hindrances, environmental aspects and environmental co-ordinators in Swedish universities. Int. J. Sustain. High Educ. $6(1), 18-35$.

Sammalisto, K., Brorson, T., 2008. Training and communication in the implementation of environmental management systems (ISO 14001): a case study at the University of Gävle, Sweden. J. Clean. Prod. 16 (3), 299-309.

Savely, S.M., Carson, A.I., Delclos, G.L., 2007. A survey of the implementation status of environmental management systems in US colleges and universities. J. Clean. Prod. 15 (7), 650-659.

Shriberg, M., 2002. Institutional assessment tools for sustainability in higher education: strengths, weaknesses, and implications for practice and theory. High. Educ. Policy 15, 153-167.

Srivetbodee, S., Igel, B., Kraisornsuthasinee, S., 2017. Creating social value through social enterprise marketing: case studies from Thailand's food-focused social entrepreneurs. J. Soc. Entrepren. 8 (2), 201-224.

Szopik-Depczyńska, K., Cheba, K., Bąk, I., Kiba-Janiak, M., Saniuk, S., Dembińska, I., Ioppolo, G., 2017. The application of relative taxonomy to the study of disproportions in the area of sustainable development of the European Union. Land Use Pol. 68, 481-491.

Tauchen, J., Brandli, L.L., 2006. A gestão ambiental em instituições de ensino superior: modelo para implantação em campus universitário. Gest. Prod. 13, 503-515. https://doi.org/10.1590/S0104-530X2006000300012.

Velazquez, L., Munguia, N., Sanchez, M., 2005. Deterring sustainability in higher education institutions: an appraisal of the factors which influence sustainability in higher education institutions. Int. J. Sustain. High Educ. 6 (4), 383-391.

Velazquez, L., Munguia, N., Platt, A., Taddei, J., 2006. Sustainable university: what can be the matter? J. Clean. Prod. 14 (9-11), 810-819.

Vierbahn, P., 2002. An environmental management model for universities: from environmental guidelines to staff involvement. J. Clean. Prod. 10, 3-12.

Wilson, D., Purushothaman, R., 2003. Dreaming with BRICs: the Path to 2050. Global Economic Paper, No 99. Goldman Sachs Global Research Centre, New York.

World Economic Forum, 2017. Disponível Em. https://www.weforum.org/agenda/ 2017/03/worlds-biggest-economies-in-2017/. (Accessed 27 October 2017).

Yin, R.K., 2013. Case Study Research: Design and Methods. Sage publications.

Yin, R.K., 2001. Study of Case: Planning and Method, 2nd ed. Bookman, Porto Alegre (Portuguese). 